\title{
STUDIES ON COPPER METABOLISM. IX. THE TRANSPORTATION OF COPPER IN BLOOD ${ }^{1}$
}

\author{
By C. J. GUBLER, M. E. LAHEY,2 G. E. CARTWRIGHT, AND M. M. WINTROBE \\ (From the Departments of Medicine and Pediatrics, University of Utah College of Medicine, \\ Salt Lake City, Utah)
}

(Submitted for publication September 30, 1952; accepted January 21, 1953)

The isolation and identification of the copper protein from serum have clarified the problem of the nature of serum copper $(1,2)$. This blue protein, ceruloplasmin, is an $\alpha$-globulin with a molecular weight of approximately 151,000 and contains eight atoms of copper. Ceruloplasmin has true oxidase activity and since it acts on paraphenylene diamine and polyphenols but not on monophenols and monoamines, it has been classified as a laccase $(3,4)$. Most if not all of the copper in normal human or pig serum is stated to be present in the form of this blue protein. The copper in serum obtained from pregnant women and from patients with infections and other diseases, like ceruloplasmin, is precipitated by 50 per cent saturation with ammonium sulfate. Furthermore, the ability of serum to oxidize paraphenylene diamine is proportional to the copper content not only in normal serum but also in serum obtained from the umbilical vein, from pregnant women and from patients with infections (5). Presumably then, in patients with hypercupremia the copper is in the form of ceruloplasmin.

The problem still remains as to whether or not ceruloplasmin serves the function of transporting newly absorbed copper from the gastro-intestinal mucosa to the liver. Since the concentration of copper (ceruloplasmin) in normal human serum is relatively constant and is not influenced by meals or by the ingestion of copper (6-8), it seems unlikely that this protein is concerned in the active transport of copper. More important is the observation (1) that the copper in ceruloplasmin does not react directly with sodium diethyldithiocarbamate, whereas copper added to serum in vitro does react directly with this reagent (9). This would indicate that, unlike the ability of serum to

1 This investigation was supported by a research grant from the National Institutes of Health, Public Health Service.

2 National Research Council Fellow in the Medical Sciences, 1949-1951. bind iron, there is no reserve capacity of normal serum to bind additional amounts of copper in the form of ceruloplasmin. It would also seem unlikely that newly absorbed copper would be transported to the liver in the form of an active enzyme.

It has been demonstrated (10) that the crystalline $\beta_{1}$ metal-binding globulin (transferrin) isolated from plasma interacts with copper at $\mathrm{pH} 7.4$ although maximal binding occurs at $\mathrm{pH}$ 8.5. At $\mathrm{pH} 7.4$ iron readily replaces copper and copper cannot replace iron. It has been suggested that this protein may be concerned in transporting newly absorbed copper to the liver (10). Observations made by Holmberg and Laurell (1), however, suggest that the metal-binding protein does not function in the transportation of copper.

The purpose of this paper is to present data concerning the type of binding of copper added both in vivo and in vitro to plasma of normal and abnormal human subjects as well as to that of rats, pigs and dogs. Data are also presented on the relation of erythrocyte copper to plasma copper.

This work has been in progress since 1949 and two preliminary reports have been published ( 8 , 11).

\section{METHODS}

Plasma and red cell copper determinations were performed by the method developed in this laboratory (12). The copper in plasma which reacts with sodium diethyldithiocarbamate when this reagent is added directly to plasma is referred to as the "direct-reacting" copper fraction. The difference between the total plasma copper determined following the liberation of the copper from the protein by acid and the direct-reacting copper is referred to as the "indirect-reacting" fraction.

The direct-reacting fraction of plasma copper was measured by adding $0.5 \mathrm{ml}$. of a saturated solution of sodium pyrophosphate and $2.5 \mathrm{ml}$. of redistilled water to $1.0 \mathrm{ml}$. of plasma. The optical density (D1) was measured with a spectrophotometer (Beckman Model DU or $B$ with cells having a $1.0 \mathrm{~cm}$. light path) at a wave length of $440 \mathrm{~m} \mu$. Two-tenths $\mathrm{ml}$. of a 0.1 per cent aqueous solution of sodium diethyldithiocarbamate was then added 
and the optical density (D2) was again read after a suitable time interval. A reagent blank consisting of $3.5 \mathrm{ml}$. water, $0.5 \mathrm{ml}$. of pyrophosphate and $0.2 \mathrm{ml}$. of carbamate was prepared and the optical density (D3) determined. The $\mu$ g. of direct-reacting copper per $100 \mathrm{ml}$. of plasma were calculated from the formula:

where $f$ is

$$
\text { D2 - (D1f + D3) } \times \mathrm{K} \times 100
$$

$$
\frac{\text { volume before addition of carbamate }}{\text { volume after addition of carbamate }}=0.952
$$

$\mathrm{K}$ is the constant derived from the standard curve prepared as described previously (12).

The $\mathrm{pH}$ of the final reaction mixture was approximately 8. Dog and pig plasma required less than five minutes for maximal color development after the addition of carbamate while human and rat plasma required 20 minutes.

Dialysis of plasma or red cells was carried out in cellophane tubing $(1 \mathrm{~cm}$. diameter) which had been treated previously with dilute acid and thoroughly rinsed with redistilled water. Five ml. of plasma or red cells of known copper content were pipetted into a suitable length of tubing tied at one end. After tying the other end, the tubing was suspended in a relatively large volume of an appropriate buffer and allowed to dialyze with occasional agitation for 18 hours at $2^{\circ} \mathrm{C}$. The dialysate was changed twice during the 18 hours. Dialysis for a greater period of time did not result in the further removal of copper. After dialysis the volume of the sample in the tubing was measured and the copper content of the dialyzed red cells or plasma was determined.

Copper was added to plasma in vitro in the form of a solution of cupric sulfate. When copper sulfate was administered intravenously to dogs, a solution containing 1 mg. of copper per ml. was injected into the jugular vein. Two hundred and fifty $\mathrm{mg}$. of Cupralene ${ }^{3}$ dissolved in $150 \mathrm{ml}$. of water were administered orally to fasting human subjects. For the intravenous injections of copper in human subjects, $100 \mathrm{mg}$. of Cupralene were dissolved in $15 \mathrm{ml}$. of sterile physiologic saline and injected rapidly into an antecubital vein.

Adult male rats of the Sprague-Dawley strain were used in this study. One-tenth ml. of turpentine (Rexall Rectified Oil of Turpentine, U.S.P.) was injected in order to produce a sterile intramuscular abscess (13). Weanling rats were made deficient in copper by feeding a condensed milk diet supplemented with iron (14). Blood was withdrawn from the abdominal aorta and potassium oxalate was used as an anticoagulant.

\section{RESULTS}

Plasma copper. Total plasma copper and direct-reacting copper measurements were made on human, rat, dog and pig plasma and the results are presented in Table I.

\footnotetext{
${ }^{8}$ Allycuprothiocarbamide containing 19.93 per cent copper.
}

TABLE I

\begin{tabular}{|c|c|c|c|c|c|c|}
\hline \multirow{2}{*}{$\begin{array}{l}\text { Species } \\
\text { Condition }\end{array}$} & \multicolumn{2}{|c|}{ Human } & \multicolumn{2}{|c|}{ Rat } & \multirow{2}{*}{$\begin{array}{c}\text { Dog } \\
\text { Normal }\end{array}$} & \multirow{2}{*}{$\begin{array}{c}\text { Pig } \\
\text { Normal }\end{array}$} \\
\hline & Normal & $\begin{array}{l}\text { Preg- } \\
\text { nant }\end{array}$ & Normal & $\begin{array}{l}\text { Turpen- } \\
\text { tine- } \\
\text { injected }\end{array}$ & & \\
\hline $\begin{array}{l}\text { Number } \\
\text { Plasma Cu } \\
\mu \mathrm{g} . / 100 \mathrm{ml} .\end{array}$ & $\begin{array}{r}7 \\
110\end{array}$ & $\begin{array}{r}8 \\
228\end{array}$ & 107 & 208 & $\begin{array}{r}7 \\
77\end{array}$ & $\begin{array}{r}2 \\
172\end{array}$ \\
\hline 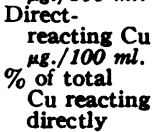 & $\left(\begin{array}{c}4 \\
(0-17)\end{array}\right.$ & $\begin{array}{c}18 \\
\\
8 \\
(0-17) \\
?\end{array}$ & 1 & 3 & $\begin{array}{c}12 \\
(0-27)\end{array}$ & $\left(40^{42}-43\right)$ \\
\hline
\end{tabular}

Total and direct-reacting plasma copper

* Pooled specimens.

In normal human plasma approximately 4 per cent of the plasma copper reacted directly with sodium diethyldithiocarbamate at $\mathrm{pH}$ 8.0. In hypercupremic plasma of pregnancy the absolute amount of direct-reacting copper increased as well as the per cent of the total. However, 85 per cent of the additional copper in this plasma was in the indirect-reacting fraction. In plasma from normal rats, 1 per cent of the copper was in the directreacting fraction. In plasma with a high total copper content obtained from rats in which sterile turpentine abscesses had been produced, a similar amount of the total copper reacted directly. In

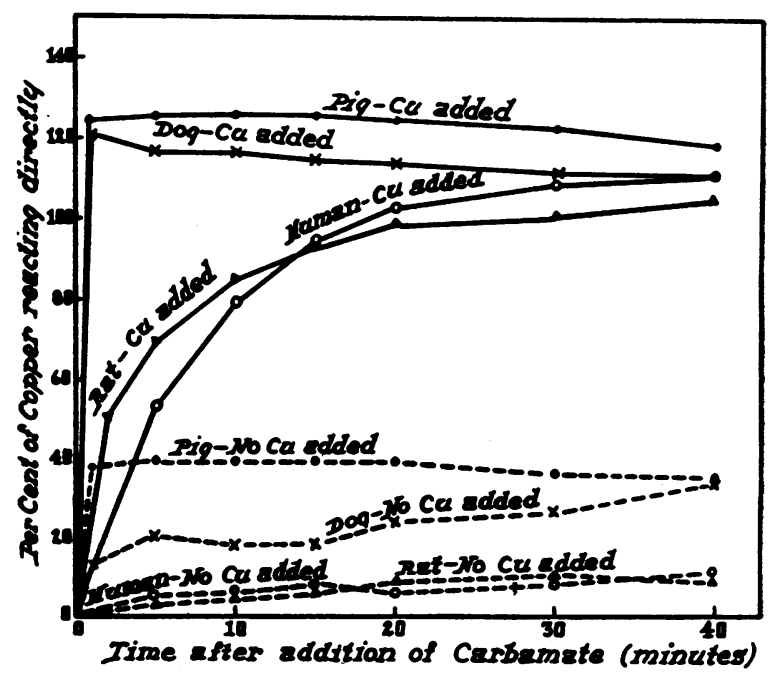

Fig. 1. The Rate of Reaction of Carbayate with Direct-reacting Copper in the Plasma of Several Spectes Before and After the Adpition of Copper in the Form of Copper Sulfate

The values for the plasma with no added copper are expressed in per cent of the total plasma copper. The values for the plasma with added copper are expressed in per cent of added copper. 
plasma from normal dogs and pigs the directreacting fraction was higher than in man and rats, being 12 and 42 per cent of the total copper, respectively.

The rate at which the copper combines with the carbamate reagent was studied in human, rat, dog and pig plasma. As can be seen in Figure 1, the reaction rate varied markedly between the species. The rate was slowest in human and rat plasma and most rapid in pig plasma.

Copper added to plasma in vitro. Amounts of copper ranging from 100 to $800 \mu \mathrm{g}$. per $100 \mathrm{ml}$. were added in vitro to human, rat, dog and pig plasma and measurements were made of the reactivity of the copper added. The results are presented in Table II.

In human, dog and pig plasma all of the copper added could be accounted for in the direct-reacting fraction. This was true for both normal human plasma and hypercupremic pregnancy plasma and was independent of the amount of copper added or the initial level. In all three species, the direct-reacting fraction was greater than the amount of copper added. This discrepancy was consistent and was greater than could be accounted for in the error of the method. Thus it would appear that the addition of copper caused a portion of the original indirect-reacting copper to react directly. In normal and hypercupremic rat plasma this influence of added copper was not observed. Only 82 to 96 per cent of the added copper reacted directly.

To determine if plasma depleted of copper is capable of binding added copper so that it will not react directly with carbamate, copper was added

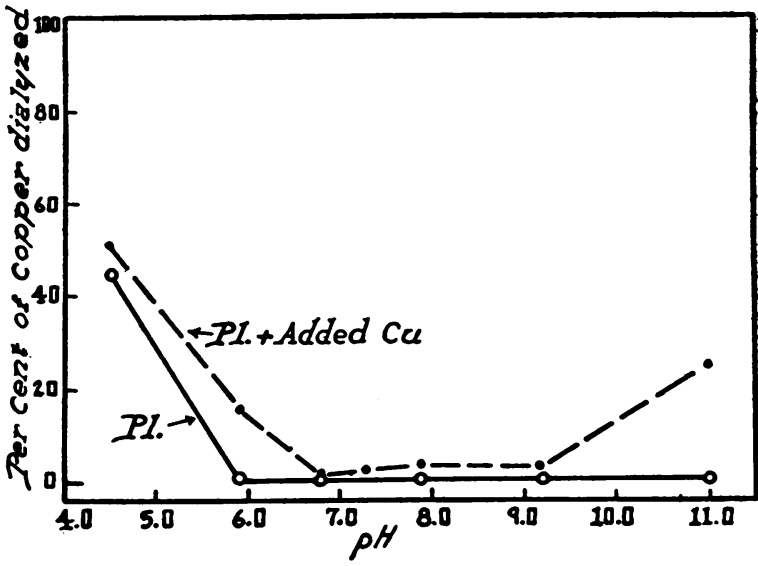

Fig. 2. The Influence of pH on the Dialyzability in 18 Hours of Copper in Nattve Plasma and of Copper after the Addition of Copper Sulfate to Plasma

to plasma obtained from copper-deficient rats. In spite of the fact that the copper level in such plasma was reduced from the normal of $107 \mu \mathrm{g}$. per $100 \mathrm{ml}$. to $18 \mu \mathrm{g}$. per $100 \mathrm{ml}$., 90 to 102 per cent of the copper added reacted directly with the carbamate reagent, indicating that there was no latent capacity to bind copper in the form in which most of it is bound normally in plasma.

The rate at which added copper reacted with carbamate is shown in Figure 1. The rate was exceedingly rapid in dog and pig plasma, complete reaction taking place within five minutes. The curves for rat and human plasma are hyperbolic in shape and level off in 20 to 30 minutes. The rate was somewhat faster in rat plasma than in human plasma. In human plasma no significant difference in rate was observed when normal,

TABLE II

Total and direct-reacting plasma copper after the addition of copper in vitro

\begin{tabular}{|c|c|c|c|c|c|c|c|}
\hline \multirow{2}{*}{$\begin{array}{l}\text { Species } \\
\text { Condition }\end{array}$} & \multicolumn{2}{|c|}{ Human } & \multicolumn{3}{|c|}{ Rat } & \multirow{2}{*}{$\begin{array}{c}\text { Dog } \\
\text { Normal } \\
\end{array}$} & \multirow{2}{*}{$\begin{array}{c}\text { Pig } \\
\text { Normal } \\
\end{array}$} \\
\hline & Normal & Pregnant & Normal & Cu-deficient & $\begin{array}{c}\text { Turpentine- } \\
\text { injected }\end{array}$ & & \\
\hline $\begin{array}{l}\text { Number } \\
\text { Plasma } \mathrm{Cu} \\
\text { pq. } / 100 \mathrm{ml} .\end{array}$ & $\begin{array}{r}4 \\
159\end{array}$ & $\begin{array}{r}8 \\
228\end{array}$ & $\begin{array}{r}4 \\
107\end{array}$ & $\begin{array}{r}4 \\
18\end{array}$ & $\begin{array}{r}7 \\
198\end{array}$ & $\begin{array}{l}10 \\
83\end{array}$ & $\begin{array}{r}2 \\
172\end{array}$ \\
\hline $\mathrm{Cu}$ added $\mathrm{ml} .100 \mathrm{ml}$ & 432 & 430 & 271 & 246 & 233 & 424 & 380 \\
\hline Direct-reacting $\mathrm{Cu}$ & 496 & 506 & 246 & 236 & 214 & 523 & 546 \\
\hline $\begin{array}{l}\% \text { of } \mathrm{Cu} \text { added } \\
\text { reacting directly * }\end{array}$ & $\begin{array}{c}114 \\
(100-118)\end{array}$ & $\begin{array}{c}113 \\
(104-119)\end{array}$ & $\begin{array}{c}91 \\
(82-96)\end{array}$ & $\begin{array}{c}93 \\
(90-102)\end{array}$ & $\begin{array}{c}91 \\
(83-97)\end{array}$ & $\begin{array}{c}121 \\
(111-142)\end{array}$ & 125 \\
\hline
\end{tabular}

* Calculated by subtracting the amount of direct-reacting copper in the plasma prior to the addition of copper from the amount of direct-reacting copper after the addition of copper, and dividing by the amount of copper added to the plasma. 
chronic leukemia (normal plasma copper), pregnancy (high plasma copper), or other pathological plasma samples were used.

The influence of $\mathrm{pH}$ on the dialyzability of native plasma copper (indirect-reacting) and on the dialyzability of copper added to plasma in vitro (direct-reacting) was studied in order to determine if the two types of copper binding could be differentiated in this manner. The results are presented in Figure 2. It will be seen that no copper dialyzed from the native plasma within the $\mathrm{pH}$ range of 6 to 11 . Below $\mathrm{pH} 6$ the copper became dialyzable. On the other hand, copper added to plasma seemed to be more labile and was dialyzable above $\mathrm{pH} 9$ and below $\mathrm{pH} 7$.

Plasma copper after the oral administration of copper. Two hundred and fifty $\mathrm{mg}$. of Cupralene, containing approximately $50 \mathrm{mg}$. of copper, were administered orally to each of three fasting normal human subjects. Attempts to study blood copper changes, at intervals after the ingestion of copper sulfate or copper acetate in doses of 150 to 200 mg., met with failure because of the emetic action of these inorganic compounds. The ingestion of the above dose of Cupralene was followed by nausea and mild, transient abdominal cramps, but not by vomiting. The changes in plasma and red cell copper after the administration of Cupralene are shown in Figure 3.

In none of the three subjects given Cupralene orally was there a significant change in the plasma

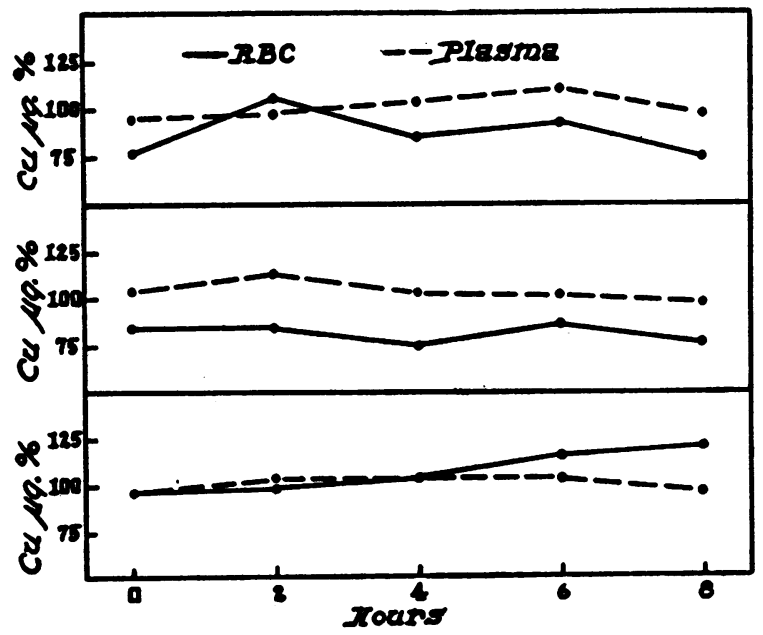

Fig. 3. Plasma and Red Blood Cell Copper in Three Normal Human Subjects Following the Oral Administration of 50 mg. of Copper in the Form of Cupralene

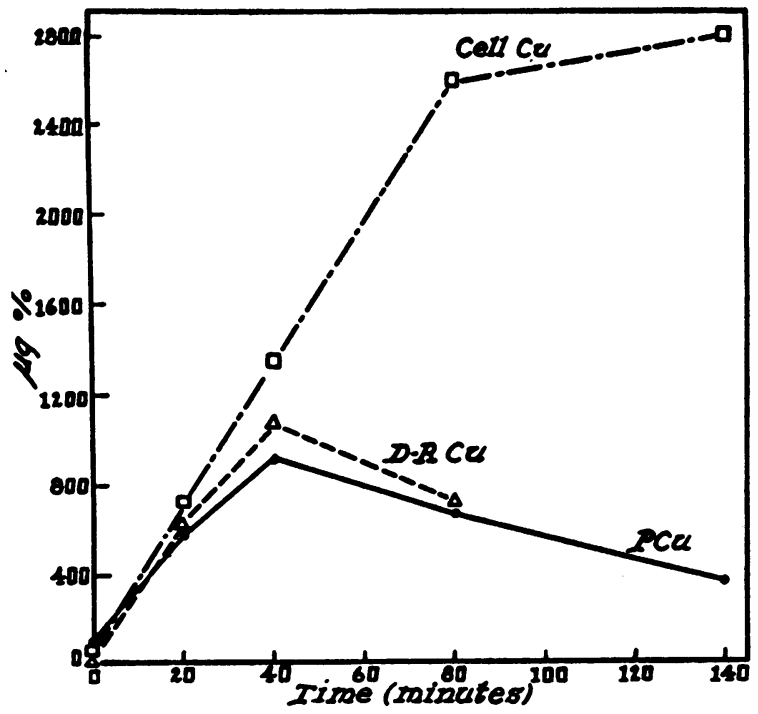

Fig. 4. Total Plasma Copper (P.Cu), Directreacting Plasma Copper (D-R Cu) and Red Cell Copper (Cell Cu) in a Dog at Various Intervals of Time after the Oral Administration of 165 mg. of COPPER PER KG. Body Weight IN THE Form of COPPER Sulfate

copper during the eight hour period of study. The erythrocyte copper values were not so uniformly stable but no significant or consistent increase in direct-reacting copper could be detected in the eight hour period.

A dog was given $165 \mathrm{mg}$. of copper per $\mathrm{kg}$. of body weight in the form of copper sulfate in a single oral dose in order to study the type of binding of copper which is in the process of transportation to the liver. This amount of copper sulfate caused vomiting and death of the dog four hours later. The changes in total plasma copper, directreacting copper, and red cell copper are shown in Figure 4.

A considerable amount of copper was absorbed, as evidenced by the increase in the plasma copper level from $100 \mu \mathrm{g}$. per $100 \mathrm{ml}$. to $910 \mu \mathrm{g}$. per 100 $\mathrm{ml}$. in 40 minutes. All of the copper appearing in the plasma reacted directly with carbamate. More surprising was the fact that the red cell copper level increased from $75 \mu \mathrm{g}$. per $100 \mathrm{ml}$. to $2800 \mu \mathrm{g}$. per $100 \mathrm{ml}$. During the period 40 to 140 minutes after the copper was given, the red cell copper continued to increase while the plasma copper level decreased from 900 to $360 \mu \mathrm{g}$. per $100 \mathrm{ml}$. Approximately two hours after the copper was given, 89 per cent of the copper in the blood was in the 
erythrocytes and only 11 per cent was in the plasma.

Plasma copper after the intravenous administration of copper. In order to study the form in which copper is transported in blood after the intravenous administration of copper, Cupralene was administered intravenously to three normal human subjects and to one dog. Seven dogs were given copper sulfate intravenously. The results are summarized in Table III. In the human subject, 90 per cent of the copper which appeared in the plasma after the administration of Cupralene reacted directly with carbamate. In the dog, all of the copper in the plasma after the administration of copper sulfate reacted directly with carbamate. Apparently, as a result of experimental error, the mean direct-reacting copper was slightly greater than the total plasma copper.

The changes in total plasma copper, direct-reacting copper, and red cell copper at various intervals of time after intravenous administration of copper are shown in detail in Figure 5 (Cupralene;

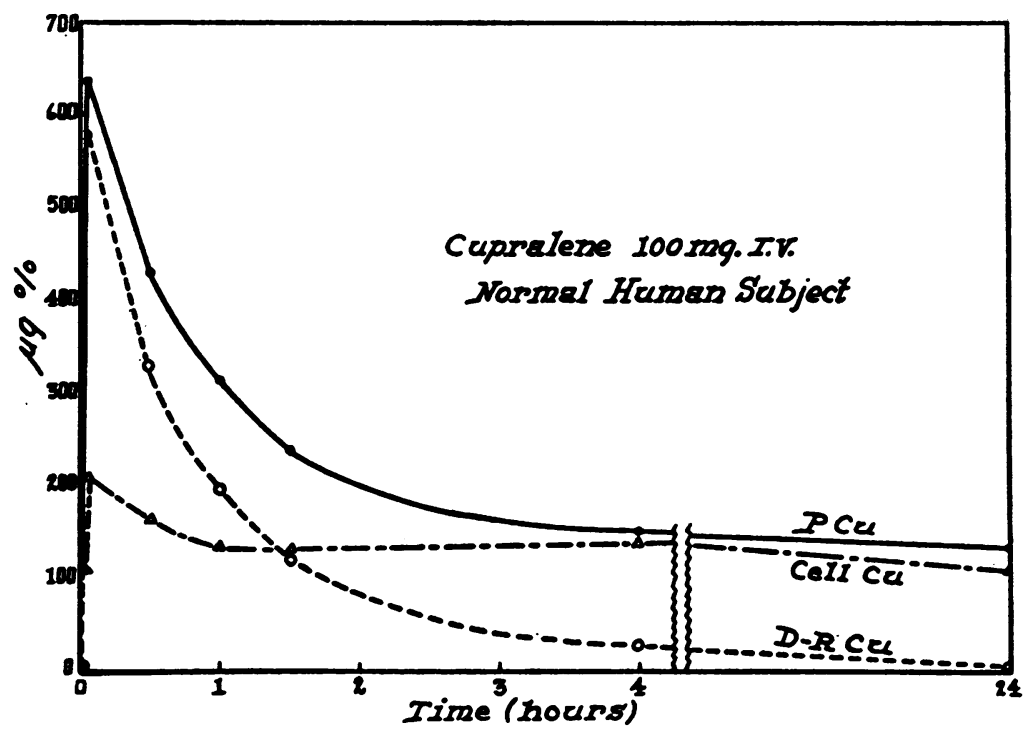

Fig. 5. Total Plasma Copper (P.Cu), Direct-reacting Plasma Copper (D-R Cu) and Red Cell Copper (Cell Cu) in a Normal Human Subject at Various Intervals of Time after the Intravenous AdMinistration of 20 Mg. OF Copper in the Form of Cupralene

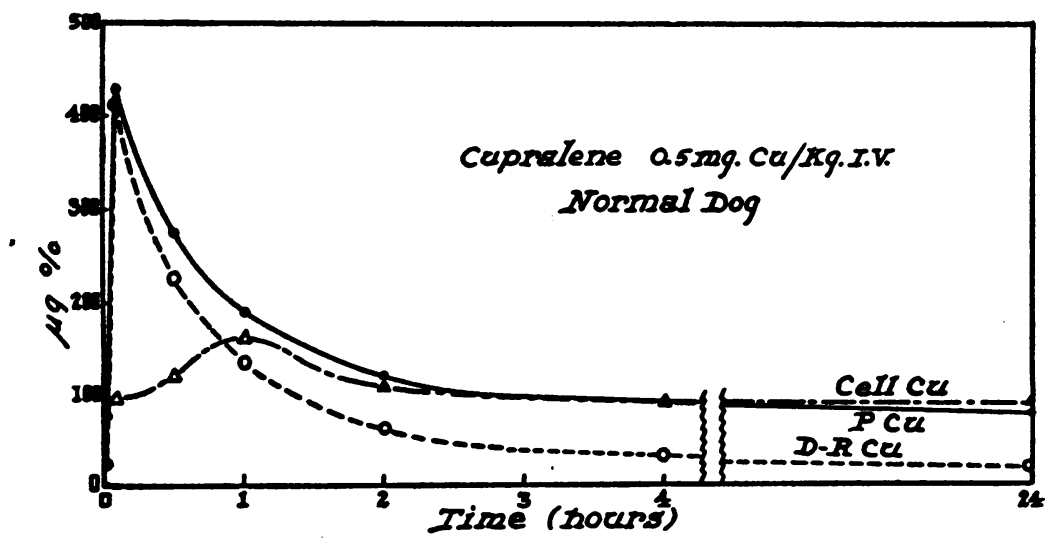

Fig. 6. Total Plasma Coppre (P.Cu), Direct-reacting Plasma Copper (D-R Cu) and Red Ceur Coppra (Cell Cu) in a Noryal Dog aftre the Intravenous Administration of 0.5 yg. of Copper per KG. Body Wetght in the Form of Cupralene 
TABLE III

Total and direct-reacting plasma copper before and ten minutes after the intravenous administration of copper

\begin{tabular}{|c|c|c|c|c|}
\hline \multirow[b]{2}{*}{ Fraction } & \multicolumn{2}{|c|}{ Human } & \multicolumn{2}{|c|}{ Dog } \\
\hline & Before & After & Before & After \\
\hline $\begin{array}{l}\text { Total plasma copper } \\
\mu g . / 100 \mathrm{ml} .\end{array}$ & 127 & 639 & 77 & 691 \\
\hline $\begin{array}{l}\text { Direct-reacting plasma } \\
\text { copper } \mu \mathrm{g} . / 100 \mathrm{ml} .\end{array}$ & 4 & 578 & 9 & 737 \\
\hline
\end{tabular}

The determinations were made in three normal human subjects after the i.v. administration of $20 \mathrm{mg}$. of copper in the form of "Cupralene"; in seven dogs after the i.v administration of $0.5 \mathrm{mg}$. of copper $/ \mathrm{kg}$. in the form of copper sulfate. The values given are the means for each group.

normal human subject); Figure 6 (Cupralene; normal dog); and Figure 7 (copper sulfate; normal dog).

Following the administration of Cupralene to the human subject (Figure 5) or a dog (Figure 6 ), the rate of clearance of the copper from the plasma was rapid and complete in about four hours even though the initial ten minute levels were above $400 \mu \mathrm{g}$. per $100 \mathrm{ml}$. This rapid decrease was due to a decrease in the direct-reacting fraction. A significant increase in red cell copper was observed in both species. In man, this in-

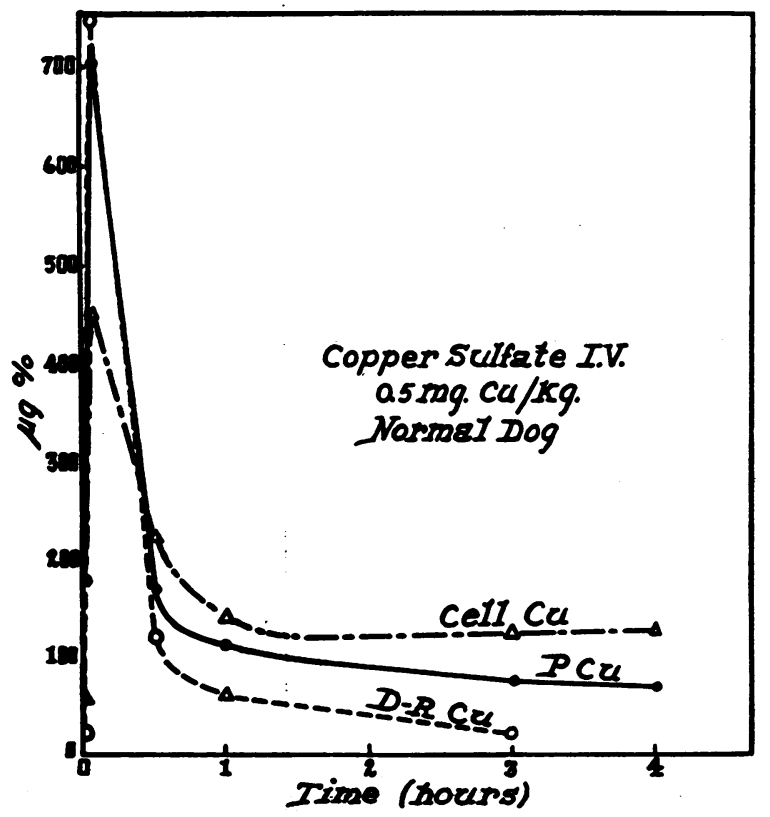

Fig. 7. Total Plasma Copper (P.Cu), Drrectreacting Plasma Copper (D-R Cu) and Red Cerl Copper (Cell Cu) in a Normal Dog after the Intravenous Administration of 0.5 Mg. OF Copper PER kg. Body Weight in the Form of Copper Sulfate: crease occurred within ten minutes after the injection. The red cell copper returned slowly to the baseline value during the first 24 hours. In the dog the red cell copper increase was maximal one hour after the injection and returned to the baseline value within three hours after the injection. The rate of removal from the plasma of intravenously injected copper sulfate was more rapid than the removal of Cupralene. In the dog, following the administration of copper sulfate the plasma copper level rose above $700 \mu \mathrm{g}$. per $100 \mathrm{ml}$. and decreased to near the baseline value within 30 minutes. There was a considerably greater and earlier increase in red cell copper following the administration of copper sulfate to dogs than following the administration of Cupralene. Thus

TABLE IV

The reactivity with sodium diethyldithiocarbamate of copper added to bovine serum albumin and to human $\beta_{1}$ metal-binding globulin as compared with copper added to normal human serum

\begin{tabular}{|c|c|c|c|}
\hline & $\begin{array}{c}\text { Cu added } \\
\mu \mathrm{g} . / 100 \mathrm{ml} .\end{array}$ & $\begin{array}{l}\text { Direct- } \\
\text { reacting Cu } \\
\mu \mathrm{g} . / 100 \mathrm{ml} .\end{array}$ & $\begin{array}{c}\% \text { of } \\
\text { Cu added } \\
\text { reacting } \\
\text { directly }\end{array}$ \\
\hline $\begin{array}{l}\text { Bovine albumin * } \\
\text { Human } \beta_{1} \text { globulin * } \\
\text { Human serum }\end{array}$ & $\begin{array}{l}342 \\
342 \\
456\end{array}$ & $\begin{array}{l}310 \\
305 \\
478\end{array}$ & $\begin{array}{r}91 \\
88 \\
104\end{array}$ \\
\hline
\end{tabular}

The measurements were made 15 minutes after the addition of copper.

* 2.5 per cent solution (wt./vol.).

the red cell membrane appears to be more permeable to this inorganic compound than to the organic compound, Cupralene.

Copper albumin and copper $\beta_{1}$ metal-binding globulin. Since it has been suggested that copper may be transported by being bound to albumin (15) or to the $\beta_{1}$ metal-binding globulin (10), and since the data presented above indicate that copper added to plasma is not bound in the same manner as the native plasma copper, the combination of copper with bovine serum albumin and human metal-binding globulin (Cohn fraction IV-7) was studied. The results are presented in Table IV. Eighty-eight to 91 per cent of the copper combined with either of these proteins reacted directly with carbamate.

The transfer of copper between cells and plasma. When copper is added to plasma and the plasma is incubated with red cells, there is an appreciable movement of copper into the red cells. 
TABLE V

The partition of copper between plasma and red cells after the addition of copper

Increasing quantities of a solution of copper sulfate $(1000 \mu \mathrm{g} . / \mathrm{ml}$.) were added to $10 \mathrm{ml}$. aliquots of pooled rat blood (V.P.R.C., $48 \mathrm{ml}$./100 ml.). The mixture was incubated at $37^{\circ} \mathrm{C}$ for four hours. The results are expressed in $\mu \mathrm{g}$. of added copper recovered in the plasma and the cells. The failure of columns (2) and (3) to equal column (1) is explained by technical variation.

\begin{tabular}{|c|c|c|c|}
\hline $\begin{array}{c}\text { (1) } \\
\mathrm{Cu} \text { added }\end{array}$ & $\begin{array}{c}\text { (2) } \\
\text { Plasma } \mathrm{Cu}\end{array}$ & $\begin{array}{c}\text { (3) } \\
\text { RBC Cu }\end{array}$ & $\begin{array}{c}(4) \\
\% \text { of added } \\
\text { Cu in } R B C\end{array}$ \\
\hline $\begin{array}{r}\text { Hg. } \\
18 \\
36 \\
91 \\
182 \\
364 \\
546 \\
728 \\
909\end{array}$ & $\begin{array}{r}\text { Mg. } \\
13 \\
30 \\
70 \\
163 \\
293 \\
451 \\
631 \\
792\end{array}$ & $\begin{array}{r}\boldsymbol{\mu g} . \\
3 \\
5 \\
13 \\
27 \\
50 \\
78 \\
106 \\
136\end{array}$ & $\begin{array}{l}16.6 \\
13.8 \\
14.3 \\
14.8 \\
13.8 \\
14.3 \\
14.6 \\
15.0\end{array}$ \\
\hline
\end{tabular}

This is shown in Table V. Various amounts of copper, in the form of copper sulfate, were added to whole blood (rat). The blood was then incubated at $37^{\circ} \mathrm{C}$. for four hours. The red cell copper increased with increasing amounts of copper added to the whole blood. Washing the cells five times with saline did not remove the copper and the copper remained non-dialyzable even after complete hemolysis of the cell. The per cent of the copper added which migrated into the red cells remained relatively constant at about 15 and

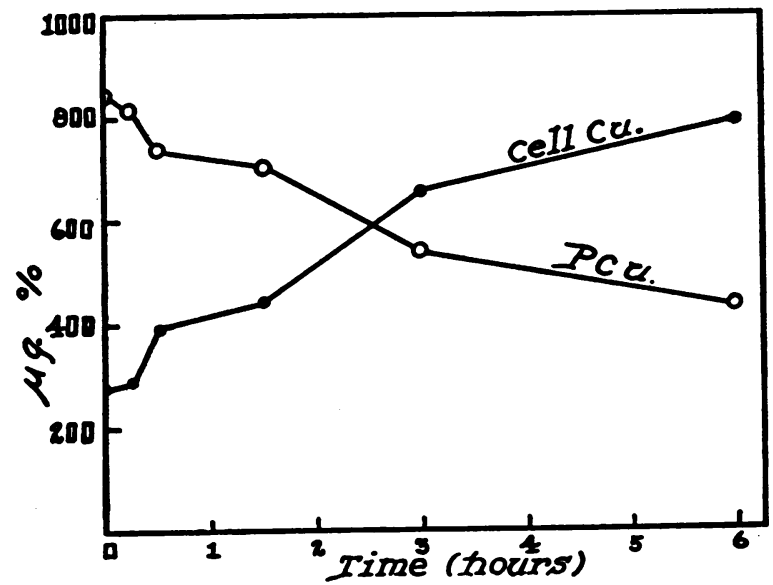

Fig. 8. Transfer of Copper from Plasma to Red Cells during Incubation of Blood

A normal dog was given $0.5 \mathrm{mg}$. of copper per $\mathrm{kg}$. of body weight intravenously in the form of copper sulfate. Two minutes following the injection a sample of blood was withdrawn from the other jugular vein and incubated for six hours at $37^{\circ} \mathrm{C}$. the ratio of plasma copper : cell copper remained constant at about 6:1 when more than $20 \mu \mathrm{g}$. of copper were added.

As shown in Figure 8, when copper sulfate is injected intravenously into a dog and a sample of blood is removed and incubated at $37^{\circ} \mathrm{C}$., there is a rather rapid shift of copper from the plasma into the cells. The same is true, as shown in Table VI, Exper. D, when Cupralene is injected into a human subject and a sample of blood is removed and incubated at $5^{\circ} \mathrm{C}$. However, when cells containing an increased amount of copper are incubated with plasma containing a normal amount of copper (Table VI, Exper. B), there is no shift of copper from the cells into plasma. Furthermore, when normal plasma and normal cells (Table VI, Exper. A) or hypercupremic plasma (pregnancy) and normal cells (Table VI, Exper. C) are incubated, there is no shift of copper from the plasma into the cells. Thus, indirect-reacting copper does not transfer from plasma to cells regardless of the plasma copper level. Directreacting copper, on the other hand, transfers readily.

\section{DISCUSSION}

From the data presented it is evident that copper is present in human, rat, dog and pig plasma bound to protein in at least two different ways.

The indirect-reacting copper which constitutes approximately $96,99,88$, and 58 per cent of the copper normally present in human, rat, dog and

TABLE VI

The transfer of copper between cells and plasma during incubation of human blood at $5^{\circ} \mathrm{C}$

\begin{tabular}{|c|c|c|c|c|}
\hline $\begin{array}{c}\text { Experi- } \\
\text { ment }\end{array}$ & Condition & $\begin{array}{c}\text { Period } \\
\text { of incu- } \\
\text { bation }\end{array}$ & $\mathbf{R B C} \mathbf{C u}$ & $\underset{\mathbf{C u}}{\text { Plasma }}$ \\
\hline & & days & $\begin{array}{c}\mu \mathrm{gg} / 100 \\
\mathrm{ml} .\end{array}$ & $\underset{\mathrm{ml} .}{\mathrm{\mu g} .1100}$ \\
\hline A & $\begin{array}{l}\text { Normal cells } \\
\text { Normal plasma }\end{array}$ & $\begin{array}{l}\mathbf{0} \\
\mathbf{3}\end{array}$ & $\begin{array}{l}124 \\
127\end{array}$ & $\begin{array}{l}87 \\
87\end{array}$ \\
\hline B & $\begin{array}{l}\text { Cells with high } \mathrm{Cu} * \\
\text { Normal plasma }\end{array}$ & $\begin{array}{l}\mathbf{0} \\
3\end{array}$ & $\begin{array}{l}400 \\
400\end{array}$ & $\begin{array}{l}63 \\
68\end{array}$ \\
\hline C & $\begin{array}{l}\text { Normal cells } \\
\text { Plasma with high } \mathrm{Cu}\end{array}$ & $\begin{array}{l}\mathbf{0} \\
\mathbf{3}\end{array}$ & $\begin{array}{l}88 \\
93\end{array}$ & $\begin{array}{l}217 \\
230\end{array}$ \\
\hline D & $\begin{array}{l}\text { Cells with high } \mathrm{Cu} \\
\text { Plasma with high } \mathrm{Cu}\end{array}$ & $\begin{array}{l}\mathbf{0} \\
\mathbf{1}\end{array}$ & $\begin{array}{l}275 \\
790\end{array}$ & $\begin{array}{l}845 \\
435\end{array}$ \\
\hline
\end{tabular}

* Obtained from a human subject following the intravenous administration of $20 \mathrm{mg}$. of copper in the form of Cupralene. 
pig plasma, respectively, has been identified by Holmberg and Laurell $(1,2)$ as a copper a-globulin. It is primarily this fraction which increases in such conditions as pregnancy, acute leukemia, infections and other pathological conditions in human subjects $(1,5,16,17)$ and following experimentally induced fever in animals (14).

The remainder of the copper in plasma is in a form which reacts directly with sodium diethyldithiocarbamate but which, like the indirectreacting fraction, is also not dialyzable at $\mathrm{pH}$ 7.5. The specific protein or proteins to which this fraction of the copper is bound are not known. Copper combined with serum albumin or with the $\beta_{1}$ metal-binding globulin is likewise not dialyzable within the physiologic $\mathrm{pH}$ range ${ }^{4}$ and reacts directly with carbamate. Therefore, it is possible that the direct-reacting copper fraction in plasma is bound to either or both of these proteins. The data of Holmberg and Laurell (1) suggest, however, that the metal-binding globulin does not function in this capacity. Since one of the most interesting aspects of the chemistry of copper is its ability to form complexes and to form simultaneous links to the same organic molecules, the so-called "chelation" phenomenon $(18,19)$, it would not be surprising if the direct-reacting copper is bound to several different proteins rather than to a specific copper-transporting protein such as is the case with iron (10).

From our observations and from those of Holmberg and Laurell (1-5) a concept of the functional significance of these two types of copper in plasma may be derived.

It seems unlikely that ceruloplasmin (indirectreacting fraction) serves to transport newly absorbed copper from the gastro-intestinal tract to the liver. Thus, this fraction remains relatively constant in normal human subjects and animals and is not influenced by the addition of copper to plasma or by the oral or intravenous administration of copper. Again, even in plasma of low copper content (obtained from animals deficient in copper) there is no reserve capacity to bind copper in this form. Since this copper protein has oxidase activity, it apparently represents a circulating copper-containing enzyme which is normally present in plasma and which increases in certain pathological situations.

4 Unpublished observations.
On the other hand, following the addition of copper to plasma, or following the oral or intravenous administration of copper to dogs and the intravenous administration of copper to human subjects, there is a striking increase in the directreacting copper fraction. This would seem to indicate that it is this fraction which is actively concerned in the transportation of copper to the principal storage site, namely, the liver. Since normally only small quantities of copper are absorbed daily (8) and since copper is rapidly removed from the plasma, it is not surprising that under normal circumstances this fraction represents only a small portion of the total circulating copper.

The possible role of the red cell in the transportation of copper needs mention. It is obvious from the experiments reported here that when large amounts of copper are given either orally or intravenously, a significant portion of the copper is taken up by the cells. However, since the amounts of copper given far exceeded the physiologic range and since the administration of even as much as $50 \mathrm{mg}$. of copper orally in a single dose to human subjects was not associated with a significant increase in erythrocyte copper, it would seem that this mechanism is of no physiologic importance. The amount of copper in red cells is exceedingly constant in human subjects even under pathologic circumstances associated with an increase in plasma copper $(6,16)$.

It is interesting to consider the striking differences between plasma iron and plasma copper. Plasma iron represents iron in the process of transportation from one site to another and is combined with a specific protein, the sole or, at least, the primary function of which is to transport the iron (10). Under normal circumstances only about one-third of this protein is bound to iron (20-22) so that there is a considerable capacity held in reserve. The administration of relatively small amounts of iron orally is associated with a detectable increase in the plasma iron level (23). Iron administered intravenously is removed relatively slowly over a period of 8 to 24 hours (23).

The situation in regard to copper is quite different. Normally only a very small fraction of plasma copper represents copper in an inactive form in the process of transportation (to sites where it is to be converted into a functioning 
enzyme). The greater part of the circulating copper is in the form of an active enzyme. The administration of relatively large amounts of copper orally is not associated with an increase in the plasma copper level, apparently because copper in the form in which it is bound in plasma after absorption (direct-reacting) is removed from the circulation at a rate greater than it can be absorbed.

\section{SUMMARY}

Evidence is presented that copper is present in human, rat, dog and pig plasma in at least two different forms. The fraction which reacts with sodium diethyldithiocarbamate only after removal from the protein by treatment with hydrochloric acid corresponds to the copper $\alpha$-globulin (ceruloplasmin) isolated by Holmberg and Laurell. This fraction constitutes approximately $96,99,88$ and 58 per cent of the copper normally present in human, rat, dog and pig plasma, respectively. The remainder of the copper in plasma is in a form which reacts directly with the carbamate reagent but, like the indirect-reacting fraction, is also nondialyzable within the physiologic $\mathrm{pH}$ range. The hypercupremia of pregnancy and that in infections in human subjects and in association with experimentally induced infections in animals, is due to an increase in the indirect-reacting fraction. The hypercupremia which follows the oral or intravenous administration of copper is due to an increase in the direct-reacting fraction.

\section{ACKNOWLEDGMENTS}

The Cupralene was kindly supplied by Dr. J. M. Carlisle, Merck and Co., Rahway, New Jersey. Dr. D. M. Surgenor, Department of Physical Chemistry, Harvard Medical School, generously furnished the $\boldsymbol{\beta}_{1}$ metal-binding globulin.

We are indebted to Miss Helen Ashenbrucker, Mrs. Jean Van Dilla, Mr. Ocie Hadley, and Mr. George Trappett for technical assistance.

\section{REFERENCES}

1. Holmberg, C. G., and Laurell, C.-B., Investigations in serum copper. I. Nature of serum copper and its relation to the iron-binding protein in human serum. Acta chem. Scandinav., 1947, 1, 944.

2. Holmberg, C. G., and Laurell, C.-B., Investigations in serum copper. II. Isolation of the copper containing protein, and a description of some of its properties. Acta chem. Scandinav., 1948, 2, 550.
3. Holmberg, C. G., and Laurell, C.-B., Investigations in serum copper. III. Coeruloplasmin as an enzyme. Acta chem. Scandinav., 1951, 5, 476.

4. Holmberg, C. G., and Laurell, C.-B., Investigations in serum copper. IV. Effect of different anions on the enzymatic activity of coeruloplasmin. Acta chem. Scandinav., 1951, 5, 921.

5. Holmberg, C. G., and Laurell, C.-B., Oxidase reactions in human plasma caused by coeruloplasmin. Scandinav. J. Clin. \& Lab. Invest., 1951, 3, 103.

6. Lahey, M. E., Gubler, C. J., Cartwright, G. E., and Wintrobe, M. M., Studies on copper metabolism. VI. Blood copper in normal human subjects. J. Clin. Invest., 1953, 32, 322.

7. Van Ravesteyn, A. H., Metabolism of copper in man. Acta. med. Scandinav., 1944, 118, 163.

8. Cartwright, G. E., Copper metabolism in human subjects, in A Symposium on Copper Metabolism, edited by McElroy, W. D., and Glass, B. The Johns Hopkins Press, Baltimore, 1950, pp. 274-315.

9. Keiderling, W., Ueber die Kupfer-Protein-Verbindung im Blutplasma. Klin. Wchnschr., 1950, 28, 460.

10. Surgenor, D. M., Koechlin, B. A., and Strong, L. E., Chemical, clinical and immunological studies on the products of human plasma fractionation. XXXVII. The metal-combining globulin of human plasma. J. Clin. Invest., 1949, 28, 73.

11. Gubler, C. J., Lahey, M. E., Brown, D. M., Smith, E. L., Cartwright, G. E., and Wintrobe, M. M., The form of binding of copper in serum. Federation Proc., 1951, 10, 356.

12. Gubler, C. J., Lahey, M. E., Ashenbrucker, H., Cartwright, G. E., and Wintrobe, M. M., Studies on copper metabolism. I. A method for the determination of copper in whole blood, red blood cells, and plasma. J. Biol. Chem., 1952, 196, 209.

13. Chase, M. S., Gubler, C. J., Cartwright, G. E., and Wintrobe, M. M., Studies on copper metabolism. IV. The influence of copper on the absorption of iron. J. Biol. Chem., 1952, 199, 757.

14. Gubler, C. J., Lahey, M. E., Cartwright, G. E., and Wintrobe, M. M., Studies on copper metabolism. $\mathrm{X}$. Factors influencing the plasma copper level of the albino rat. Am. J. Physiol., 1952, 171, 652.

15. Eisler, B., Rosdahl, K. G., and Theorell, H., Untersuchungen über die Zustandsform des Kupfers in Blutserum mit Hilfe der Kataphorese. Biochem. Zeitschr., 1936, 286, 435.

16. Lahey, M. E., Gubler, C. J., Cartwright, G. E., and Wintrobe, M. M., Studies on copper metabolism. VII. Blood copper in pregnancy and various pathologic states. J. Clin. Invest., 1953, 32, 329.

17. Lahey, M. E., Gubler, C. J., Brown, D. M., Smith, E. L., Jager, B. V., Cartwright, G. E., and Wintrobe, M. M., Studies on copper metabolism. VIII. The correlation of serum copper with various serum protein fraction. J. Lab. \& Clin. Med., in press. 
18. Corwin, A. H., The formation of copper complexes, in A Symposium on Copper Metabolism, edited by McElroy, W. D., and Glass, B. The Johns Hopkins Press, Baltimore, 1950, pp. 1-17.

19. Klotz, I. M., and Curme, H. G., The thermodynamics of metallo-protein combinations. Copper with bovine serum albumin. J. Am. Chem. Soc., 1948, 70, 939.

20. Rath, C. E., and Finch, C. A., Chemical, clinical and immunological studies on the products of human plasma fractionation. XXXVIII. Serum iron transport. Measurement of iron-binding capacity of serum in man. J. Clin. Invest., 1949, 28, 79.

21. Cartwright, G. E., and Wintrobe, M. M., Chemical, clinical and immunological studies on the products of human plasma fractionation. XXXIX. The anemia of infection. Studies on the iron-binding capacity of serum. J. Clin. Invest., 1949, 28, 86.

22. Laurell, C.-B., Studies on the transportation and metabolism of iron in the body with special reference to the iron-binding component in human plasma. Acta physiol. Scandinav., 1947, 14, Suppl. 46.

23. Cartwright, G. E., Lauritsen, M. A., Jones, P. J., Merrill, I. M., and Wintrobe, M. M., The anemia of infection. I. Hypoferremia, hypercupremia, and alterations in porphyrin metabolism in patients. J. Clin. Invest., 1946, 25, 65. 